This item was submitted to Loughborough's Research Repository by the author.

Items in Figshare are protected by copyright, with all rights reserved, unless otherwise indicated.

\title{
Analysis of mono-phosphate nucleotides as a potential method for quantification of DNA using high performance liquid chromatography- inductively coupled plasma-mass spectrometry
}

\section{PLEASE CITE THE PUBLISHED VERSION}

http://dx.doi.org/10.1007/s00216-011-5347-y

\section{PUBLISHER}

(C) Springer

\section{VERSION}

AM (Accepted Manuscript)

\section{LICENCE}

CC BY-NC-ND 4.0

\section{REPOSITORY RECORD}

Camp, Claire L., Barry L. Sharp, Helen J. Reid, John Entwisle, and Heidi Goenaga-Infante. 2019. "Analysis of Mono-phosphate Nucleotides as a Potential Method for Quantification of DNA Using High Performance Liquid Chromatography-inductively Coupled Plasma-mass Spectrometry". figshare.

https://hdl.handle.net/2134/13512. 
This item was submitted to Loughborough's Institutional Repository (https://dspace.lboro.ac.uk/) by the author and is made available under the following Creative Commons Licence conditions.

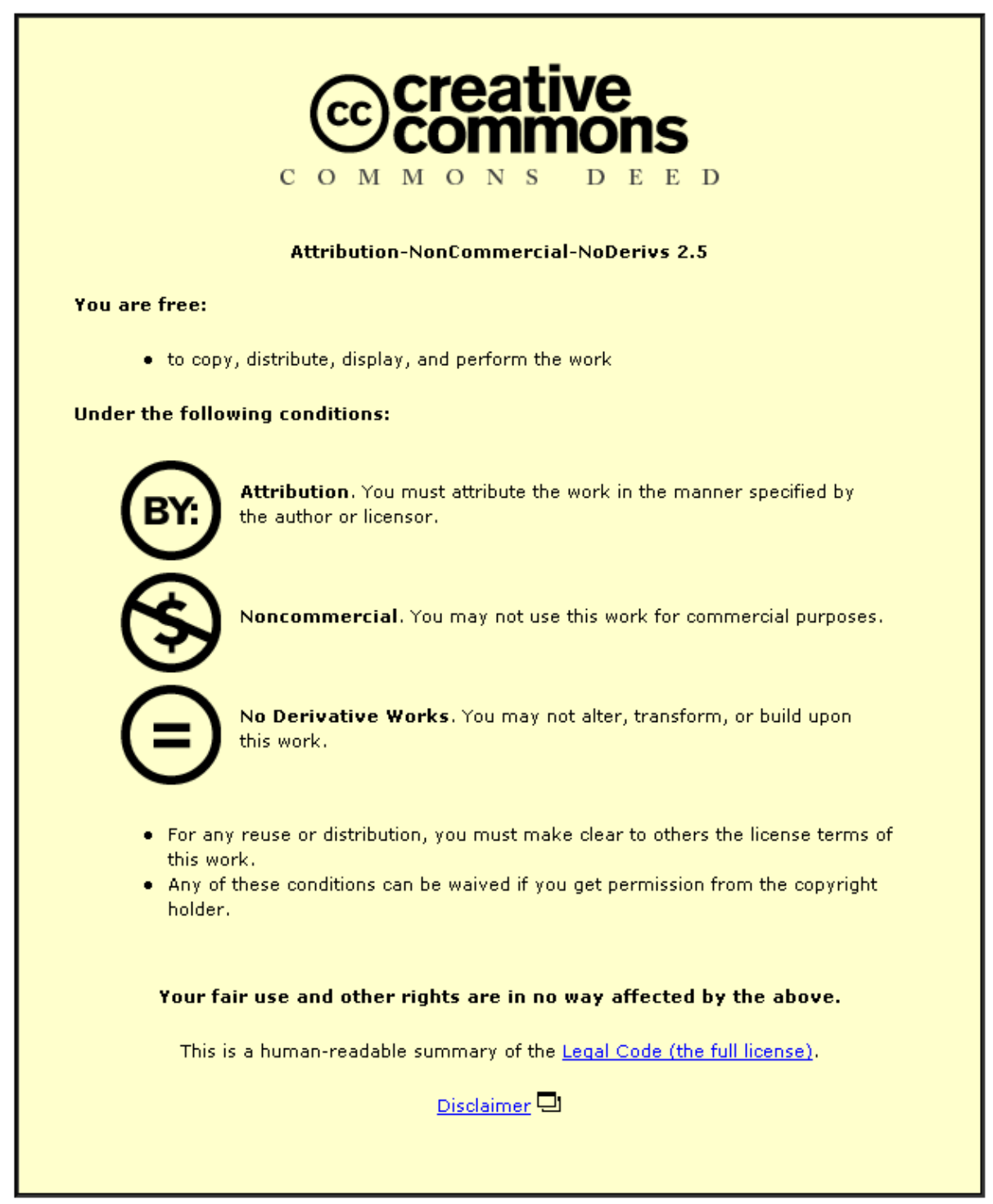

For the full text of this licence, please go to: http://creativecommons.org/licenses/by-nc-nd/2.5/ 


\title{
Analysis of Mono-phosphate Nucleotides as a Potential Method for Quantification of DNA Using High Performance Liquid Chromatography- Inductively Coupled Plasma-Mass Spectrometry
}

\author{
Claire L. Camp ${ }^{\#}$, Barry L. Sharp ${ }^{\# *}$, Helen J. Reid ${ }^{\#}$, John Entwisle, Heidi Goenga-Infante \\ ${ }^{*}$ Centre for Analytical Science, Loughborough University, Loughborough, UK, LE11 3TU \\ ${ }^{\ddagger}$ LGC, Queens Road, Teddington, Middlesex, UK, TW11 OLY \\ *B.L.Sharp@1boro.ac.uk
}

Keywords

Quantification, DNA, ICP-MS, Mass Balance, Nucleotides.

\begin{abstract}
The determination of total deoxyribonucleic acid (DNA) concentration is of great importance in many biological and bio-medical analyses. The quantification of DNA is traditionally performed by UV spectroscopy; however the results can be affected greatly by the sample matrix. The proposed method quantifies phosphorus in digested calf thymus DNA and human DNA by high performance liquid chromatography (HPLC) coupled to inductively coupled plasma mass spectrometry (ICP-MS). The method presented showed excellent baseline separation between all 4 DNA mono-nucleotides and 5'UMP. Column recoveries ranging from $95 \%$ to $99 \%$ for phosphorus resulted in a mass balance of $95 \% \pm 0.5 \%$ for standard nucleotides, determined by LC-ICP-MS, compared to total DNA determined by flow injection coupled to ICP-MS (FI-ICP-MS). The ability of LC-ICPMS to act as an internal check that only DNA derived phosphorus was counted in the assay was demonstrated by establishing a mass balance between the total phosphorous signal from undigested DNA and that from the speciated DNA. The method for quantification was evaluated by analysis of NIST SRM 2372; a total speciated DNA recovery of $52.1 \mathrm{ng} / \mu \mathrm{L}$, compared with an expected value of $53.6 \mathrm{ng} / \mu \mathrm{L}$, was determined by external calibration. From repeat measurements a mass balance of $97 \% \pm 0.5 \%$ for NIST DNA was achieved. The method limits of detection for individual nucleotides were determined between 0.8 to $1.7 \mu \mathrm{g} \mathrm{L-1}$ (31P) for individual nucleotides by LC-ICP-MS, and $360 \mathrm{ng}$ L-1 for 5'AMP by direct nebulisation.
\end{abstract}

\section{Introduction}

As one of the most important life elements, phosphorus is an integral part of a wide range of biochemical functions and structures, most notably protein phosphorylation and as the backbone of DNA. The backbone of both RNA and DNA is formed from phosphodiester linkages and due to the fixed stoichiometry of phosphorus; the quantification of such macro-molecules can be obtained via the ${ }^{31} \mathrm{P}$ signal by ICP-MS. Accurate 
quantification of DNA is of great importance for many biological, clinical and microbiological studies. Traditionally the quantification of phosphorus in bio-molecules has been achieved by UV absorbance, fluorescence via the incorporation of dyes, or by counting $\beta$ radiation emission from radioisotope labelled ${ }^{32} \mathrm{P}$ and ${ }^{33} \mathrm{P}$. Results acquired with spectrometric methods can be compromised by impurities in the sample, from RNA and metabolic molecules such as adenosine triphosphate (ATP) and require relatively large sample volumes [1]. The method presented here is able to distinguish contaminants of the DNA sample by differentiating between retention times. Recently, ${ }^{31} \mathrm{P}$, determined by ICP-MS, was used to estimate DNA yields in samples from patients undergoing Pt-based chemotherapy [2]. A robust and more accurate analytical method based on LC-ICP-MS could improve the reliability of such results.

Over the last ten years elemental mass spectrometry has been increasingly used for the quantification of metals and heteroatoms within biomolecules, including the quantitation of phosphorus within nucleotides, oligonucleotides and DNA. Elemental analysis is preferred over other techniques as it offers lower detection limits, a larger dynamic range, a response that is to a first approximation independent of molecular form, and potentially more accurate quantification at low concentrations by isotope dilution analysis. Both ICP-MS and ICP-OES have been utilised for the quantification of nucleotides, DNA, oligonucleotides and DNA adducts [315]. The quantification of oligonucleotides has been achieved by two different methods by Yang et al. [4] and Donald et al. [7], with the latter group digesting the oligonucleotides to mono-nucleosides and quantifying by isotope dilution electrospray mass spectrometry (ES-ID-MS), and comparing that value to the total ${ }^{31} \mathrm{P}$ signal obtained from ICP-OES and the gravimetric value. Styrene oxidate and mephalen DNA adducts have been investigated by elemental mass spectrometry, by Edler et al. [12, 13] and styrene -7,8-oxide adducts by Siethoff et al. [11].

One of the most attractive characteristics of quantification by ICP-MS is the ability to mass balance the element of interest before and after speciation, however, because of the many different species of phosphorus within cells, quantifying total cell phosphorus content prior to separation is of limited value, as mass balance would not be achieved. Additionally, the quantification of phosphorus containing bio-molecules is hindered by the lack of suitable molecular internal standards and significant levels of background phosphorus within biological buffers. Furthermore, the detection of phosphorus by ICP-MS is difficult due to its high first ionisation potential (10.5 $\mathrm{eV}$ ), resulting in only $\sim 33 \%$ of the element being ionised, and polyatomic interferences caused by ${ }^{14} \mathrm{~N}^{16} \mathrm{O}^{1} \mathrm{H}^{+}$ and ${ }^{15} \mathrm{~N}^{16} \mathrm{O}^{+}$. These molecular interferences can be removed in a collision/reaction cell by the addition of a collision/reaction gas such as $\mathrm{He}$ or $\mathrm{H}_{2}$, alternatively the element of interest can be reacted, e.g with $\mathrm{O}_{2}$, so that the product ion is in an area of less interference, in the case of phosphorus by the formation of ${ }^{31} \mathrm{P}^{16} \mathrm{O}$. The preferred solution is to use a sector field mass spectrometer that can resolve the spectral interferences and provides superior sensitivity.

Despite several publications citing the analysis of phosphorus from enzymatic digests of nucleic acid, the quantification of each nucleotide within such a digest had not been established until recently by Fujii et al [16] who employed capillary electrophoresis coupled to ICP-MS. Accurate quantification of phosphate within each nucleotide from a DNA digest requires complete and reproducible enzymatic digestion, under conditions compatible with the separation and detection method chosen. This work demonstrates for the first time that mass balance can be achieved for total DNA and the speciation of all 4 nucleotide standards by LC-ICP-MS. 


\section{Experimental Section}

\section{Instrumental}

Two ICP-MS instruments were used in this study, the first being an Agilent 7500 ce (Agilent Technologies, Berkshire, UK) equipped with an octopole reaction cell system (ORS) and the second a Thermo Element 2 XR, sector field instrument (Thermo Scientific, Hemel Hempstead, UK); operating conditions are given in Table 1. The Agilent 7500ce was optimized with a standard solution of $1 \mathrm{ng} \mathrm{mL}^{-1} \mathrm{Be}, \mathrm{Co}, \mathrm{In}, \mathrm{Pb}$, and $\mathrm{U}$ in normal mode, and further optimized in ORS mode for the flow rate of the reaction gases. The Element 2 XR was optimised with a standard solution of $1 \mathrm{ng} \mathrm{mL}^{-1}$ containing $\mathrm{In}, \mathrm{Li}$ and $\mathrm{Pb}$. An LTQ linear ion trap mass spectrometer was used in this study (Thermo Scientific, San Jose, USA) equipped with an electrospray ionisation (ESI) source operated in positive mode at $5.5 \mathrm{kV}$ and $280{ }^{\circ} \mathrm{C} . \mathrm{N}_{2}$ was used as the nebulisation gas with sheath, auxiliary and sweep gas flows set at 50,10, and 10 arbitrary units, respectively.

Table 1: Instrumental parameters for the elemental mass spectrometers

\begin{tabular}{|l|l|l|}
\hline ICP-MS system & $\begin{array}{l}\text { Thermo-Scientific Element 2 } \\
\text { XR }\end{array}$ & Agilent 7500ce \\
\hline Power (kW) & 1.25 & 1.57 \\
Plasma Flows (L min ${ }^{-1}$ ) & 15.5 & 15.00 ( Make-up - 0.27) \\
Auxiliary & 0.80 & 1.00 \\
Nebuliser & 1.13 & 0.87 (carrier) \\
Reaction gas (ORS mode) & N/A & Helium (3.1 mL min $\left.{ }^{-1}\right)$ \\
Resolution & Medium & Oow \\
\hline
\end{tabular}

LC-ICP-MS was conducted using an Agilent 1100 system connected to the Agilent 7500 ce using a micro-flow nebuliser (Agilent), with a cooled Scott double pass spray chamber. The Element 2 XR was connected to an HPLC system, consisting of a solvent delivery pump and micro auto-sampler (Surveyor, Thermo Scientific, Hemel Hempstead, UK), via a 0.005 " peek tube, a cyclonic spray chamber (ESI) and poly(fluoroalkoxy) (PFA) nebuliser (Elemental Scientific, Omaha, USA).

\section{Reagents}

Ultra-pure water (> $18 \mathrm{M} \Omega$ ) was obtained from a Milli Q Element system (Millipore, Herts, UK). Mobile phases were prepared by diluting triethylamine acetate (TEAA, HPLC grade, Fluka, Dorset, UK) in ultra-pure water; the $\mathrm{pH}$ was monitored using a Jenway $\mathrm{pH}$ meter. All other reagents and standards were purchased from Sigma 
Aldrich (Dorset, UK) including thymidine-5'-monophosphate (5'TMP > 98-100\%), cytidine-5'-monophospate sodium salt (5'CMPNa $\geq 99 \%$ ), guanosine-5'-monophosphate sodium salt (5'GMPNa $\geq 97 \%$ ), uridine-5'monophosphate disodium salt (5' ${ }^{\prime} \mathrm{UMNa}_{2} \geq 97 \%$ ), adenosine-5'-monophosphate (5' AMP Na $\geq 98 \%$ ), Nuclease $\mathrm{S}_{1}$ and calf thymus DNA.

Optimisation of separation conditions: The chromatographic method was developed from that of Profrock et al. [5], by altering the conditions to improve separation and changing the mobile phase from ammonium acetate to triethylamine acetate to improve compatibility with ICP-MS and using a $\mathrm{C}_{18}$ column, with high mechanical strength due to a unique organo-silica grafting process making it compatible with high aqueous loading. All separations were made using a Phenomenex Gemini NX column $(150 \times 2.1 \mathrm{~mm}, 5 \mu \mathrm{m})$ at a flow rate of 0.20 $\mathrm{mL} / \mathrm{min}$ and the column was kept at a constant $25^{\circ} \mathrm{C}$. Isocratic separations were made using TEAA $(5 \mathrm{mM}, \mathrm{pH}$ $6.5)$ as the mobile phase and samples were injected onto the column at a volume of $2 \mu \mathrm{L}$.

Calf thymus DNA enzymolysis. After parametric optimization, a total of $20 \mu \mathrm{g}$ Plasmid DNA was heated to 80 ${ }^{\circ} \mathrm{C}$ for $5 \mathrm{~min}$ at $200 \mathrm{~W}$, cooled on ice and was then incubated at $50{ }^{\circ} \mathrm{C}$ for a further 5 minutes with $20{\mathrm{U} \mu \mathrm{g}^{-1}}^{-1}$ Nuclease $\mathrm{S}_{1}$ at $55 \mathrm{~W}$.

\section{Quantification Strategy}

This strategy exploited the compound independent signal sensitivity of ICP-MS which allows quantification of complex organic molecules by calibration with inorganic metal salts. Thus prior to speciation, the flow-injected signal magnitude (area under curve) measured by ICP-MS should be equal to the total signal magnitude after speciation, provided that there is efficient recovery of species from the separation column. The proposed strategy for the quantification of calf thymus DNA is detailed in Figure 1.

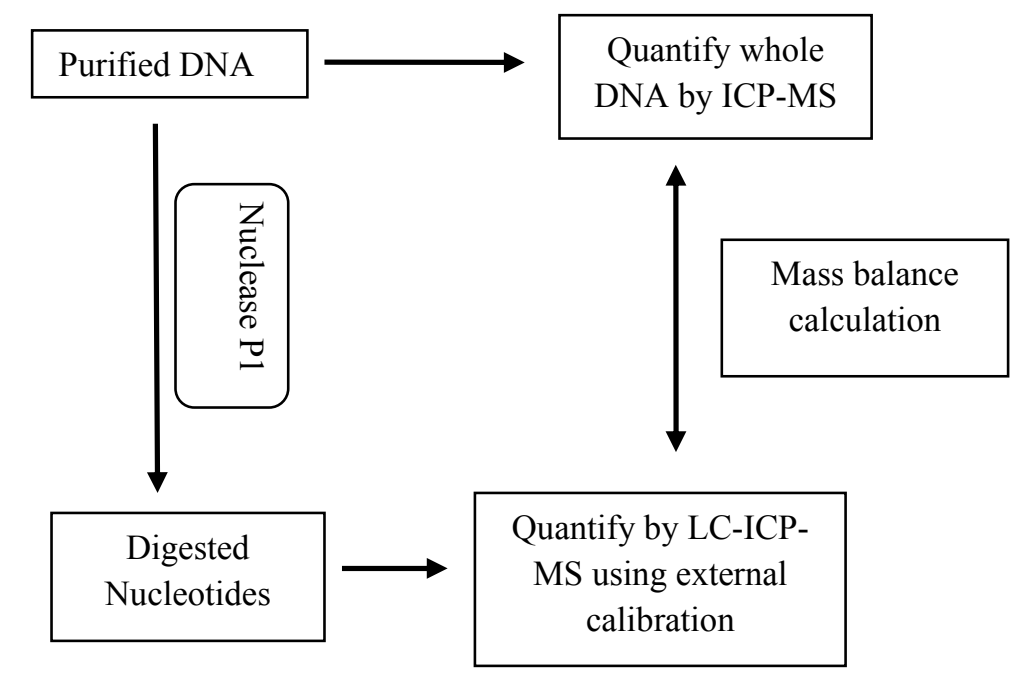

Figure 1: Proposed quantification of calf thymus DNA work-flow 


\section{Results and Discussion}

Linearity and Robustness: The data presented here were collected using LC-SF-ICP-MS, calibration curves were prepared for all 5 mono-phosphate nucleotides in the range of 5-15 ng P/g for inter-assay ( $\mathrm{n}=3$ ) and intraassay $(n=3)$. Figure 2 shows typical calibration data collected for d'AMP, d'CMP, d'GMP and TMP exhibiting good linearity with correlation coefficients of greater than 0.997 . There was no statistical difference (Test: $n=6$, $\mathrm{p}=0.95$ ) between the slopes for the 4 different nucleotides. The relative standard deviation (RSD) of the slopes for these calibration curves were $3.6 \%$ for the intra-assay and $6.5 \%$ for the inter-assay. Repeatability of injection was calculated as $0.2 \% \operatorname{RSD}(n=6)$.

Limits of Detection: LOD's for phosphorus for the standard nucleotides were calculated using the standard error of the regression data, as ranging from 0.8 to $1.7 \mu \mathrm{g} / \mathrm{L}$, by LC-SF-ICP-MS, which are similar to results reported by Fujii et al. [17] from $\mu$ LC-ICP-MS. A limit of detection of $20 \mathrm{pg}$ of $\mathrm{P}$ on column was achieved. This is significantly higher than that reported by Fujii et al. [18], but if the method reported here were to be scaled down, further improvement in the absolute limits of detection would be obtained. Limits of detection were calculated as ranging from 2.4 to $9.1 \mu \mathrm{g} / \mathrm{L}$, by ORS-ICP-MS with oxygen addition to the reaction cell, and 2.0 to $3.1 \mu \mathrm{g} / \mathrm{L}$ with helium addition. LOD's ranging from 0.3 to $2.7 \mu \mathrm{g} / \mathrm{L}$ were calculated from the standard deviation of the blank, with helium addition to the octopole reaction cell. Whilst it was expected that the LOD's obtained by the SF-ICP-MS instrument would be up to an order of magnitude lower than those obtained with the ORS-ICP-MS instrument, it was not observed as such. The high blank concentrations of phosphorus negated the better signal to noise ratio of sector field instrument.

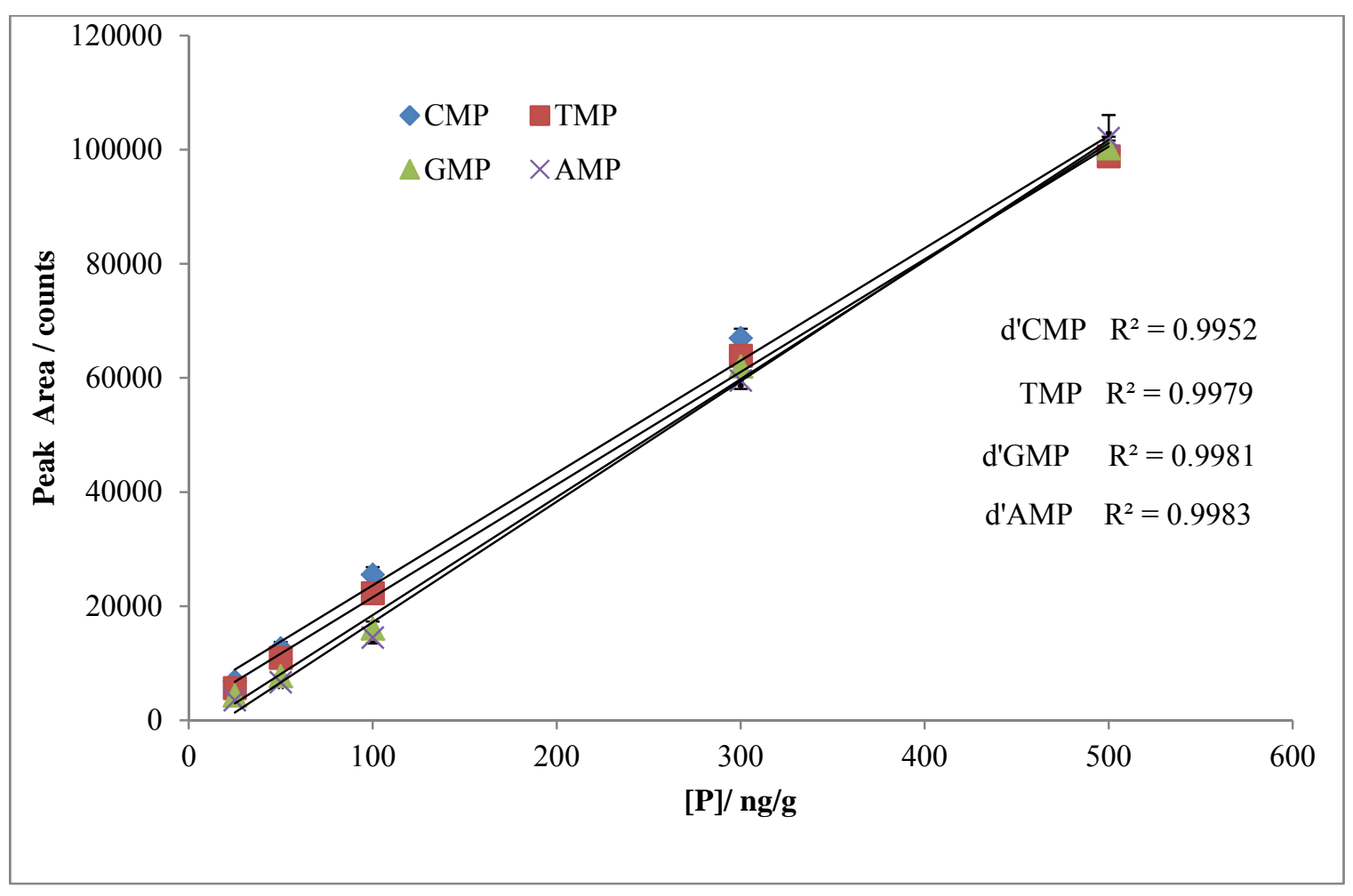

Figure 2: A typical calibration chart for nucleotide standards 
Column recoveries: These were determined for each nucleotide standard from the injection of $5 \mu \mathrm{L}$ of the nucleotide standard with and without the column in place, the recoveries ranged from 95 to $98 \%$, as shown in Table 2.

Table 2: Recoveries of individual nucleotides using FI-ICP-MS

\begin{tabular}{|l|l|}
\hline Nucleotide & \% Recovery \\
\hline d'CMP & $98.7 \pm 0.5$ \\
\hline d'TMP & $97.8 \pm 1.1$ \\
\hline d'GMP & $99.1 \pm 1.2$ \\
\hline d'AMP & $98.4 \pm 1.2$ \\
\hline UMP & $98.0 \pm 3.1$ \\
\hline
\end{tabular}

\section{Mass Balance}

A solution containing $200 \mathrm{ng} / \mathrm{g}$ of each nucleotide was prepared in $20 \mathrm{mM}$ TEAA at $\mathrm{pH} 6.4$ and analysed by LC-ICP-MS using the conditions stated in Table 1. The total peak areas for the individual nucleotide standards and that of the void volume peak were summed and compared to the peak area of a flow injection peak for the same standard solution in order to calculate the mass balance. The LC-ICP-MS results show that a mass balance of $97.2 \% \pm 0.5 \%$ was achieved by this experiment, which was expected due to the high column recoveries observed. The mass balance calculation data is shown in Table 3 for both NIST SRM DNA and nucleotide standards. Errors were calculated from the standard error of the mean for each peak in the digest and for the repeated flow injection peaks, and then treated with the propagation of errors formula.

Table 3: Total peak areas for speciated nucleotide standards and digested NIST DNA and flow injection peak areas for nucleotide blend and undigested NIST DNA.

\begin{tabular}{|c|c|c|c|}
\hline \multicolumn{4}{|c|}{ NIST DNA } \\
\hline Run & Total Peak Area / counts & Run & FIA Peak Area / counts \\
\hline 1 & 165538.4 & 1 & 169729.4 \\
\hline 2 & 160938.8 & 2 & 168704.7 \\
\hline 3 & 163914.6 & 3 & 167007.8 \\
\hline \multirow[t]{3}{*}{ Average } & 163463.9 & 4 & 167446.2 \\
\hline & & Average & 168222.0 \\
\hline & & Mass Balance & $97.2 \% \pm 0.5 \%$ \\
\hline
\end{tabular}

\begin{tabular}{|l|l|l|l|}
\hline \multicolumn{4}{|l|}{ Nucleotide Standards } \\
\hline Run & Total Peak Area / counts & Run & FIA Peak Area / counts \\
\hline 1 & 11065522 & 1 & 11398134.9 \\
\hline 2 & 11155169 & 2 & 11849337.3 \\
\hline 3 & 11348798 & 3 & 11999766.6 \\
\hline Average & 11189830 & & \\
\hline & & Average & 11749079.6 \\
\hline & & Mass Balance & $\mathbf{9 5 . 2 \%} \pm \mathbf{0 . 5 \%}$ \\
\hline
\end{tabular}


Measuring total $\mathrm{P}$ as an indicator of DNA concentration is problematic as even in highly purified and well characterised samples, such as the NIST standard, there are likely to be P-containing residues from the purification procedure.
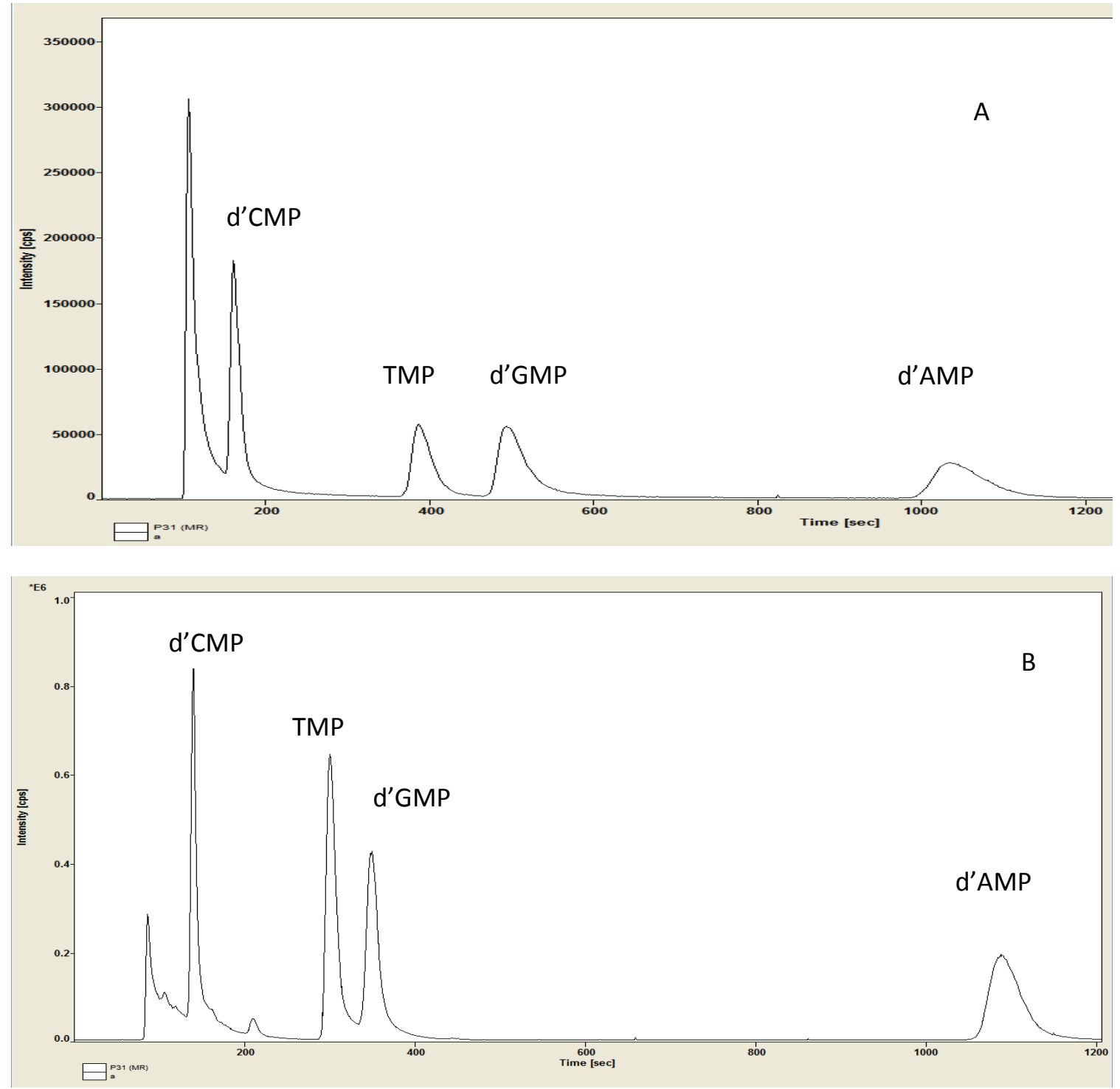

Figure 3: LC-SF-ICP-MS chromatograms of ${ }^{31} \mathbf{P}$, A: single monophosphate nucleotide standards, B: digested calf thymus DNA

Figure 3 compares the separation of a mixture of mono-nucleotide standards and digested calf thymus DNA. The slight change in the observed retention times was due to the variation in the mobile phase $\mathrm{pH}$, from non consecutive chromatograms, however, the peaks were positively identified by LC-MS. The unknown peak observed in both the nucleotide standards and the DNA digest is thought to be the result of phosphate buffers used in the purification process. The presence of these buffers did not affect the quantification of DNA when speciation was used, because the first peak can be ignored, but would affect an assay based on total P where it would be included. This was proven by fraction collecting the individual nucleotide peaks from the Sigma standards, digesting to phosphate and quantifying by direct nebulisation into the ICP-MS. This experiment was 
also performed on the DNA digest. Chromatograms run including UMP in the mixture showed the UMP baseline separated with a retention time of approximately 4.8 minutes.

LC-ESI-MS, using the same separation conditions as for LC-ICP-MS, was used to positively identify each peak by analysis of a mixture containing all 4 DNA nucleotide standards as seen in Table 4. Comparison of parent ions from the standard run and that of the digest allowed the identification of 4 out of the 5 peaks in the DNA digest LC-ICP-MS chromatogram. As indicated above, it is believed that the unknown peak observed in both the standards and the digest are phosphates from biological buffers.

Accuracy of the quantification method was evaluated by the analysis of NIST SRM 2372, component B. Component B was digested using the procedure outlined above, diluted to a final volume of $65 \mu \mathrm{L}$ and analysed by LC-ICP-MS. The phosphorus content of the 4 nucleotides was calculated by external calibration with standard nucleotides from Sigma as; d'CMP $11.2 \pm 0.1 \mathrm{ng} / \mu \mathrm{L}$, d'GMP $13.1 \pm 0.1 \mathrm{ng} / \mu \mathrm{L}, \mathrm{TMP} 13.6 \pm 0.1 \mathrm{ng} / \mu \mathrm{L}$ and d'AMP $14.2 \pm 0.1 \mathrm{ng} / \mu \mathrm{L}$, giving a total of $52.1 \mathrm{ng} / \mu \mathrm{L}$. The stated DNA concentration for component B was $53.6 \pm 0.4 \mathrm{ng} / \mu \mathrm{L}$, giving a recovery of $97.2 \%$. To further confirm the mass balance, 3 repeat flow injection analyses and two repeats digest analyses $(n=6)$ were performed. The summation of the peak areas of the digested DNA were compared to the peak area of undigested NIST DNA analysed by FI-ICP-MS which yielded a mass balance of $97 \pm 0.5 \%$. The unknown phosphate peak observed in the digest was included in the mass balance calculation.

\section{Conclusions}

Successful separation and P-selective detection of all 5 common DNA nucleotides within a timeframe of 20 minutes was achieved using reversed phase HPLC with ICP-MS detection. Limits of detection for phosphorus associated with individual nucleotides were found to be comparable with previously reported values, ranging between 0.8 to $1.7 \mu \mathrm{g} \mathrm{L}^{-1}$. Furthermore, it has been shown that a full mass balance for monophosphate nucleotides with the newly developed method is achievable. The method was validated against NIST SRM 2372 with recoveries of $97.2 \%$. The results presented here have demonstrated that DNA can be quantified at low ng/g concentrations by measuring the total P concentration from DNA using FI-ICP-MS versus the summation of the P signal peak area from the individual nucleotides following a simple digestion of whole DNA and HPLC-ICPMS analysis.

\section{Acknowledgements}

The authors would like to thank LCG, Teddington, UK for their support and DIUS and EPSRC for funding the project.

\section{References}

1. Haque K., Pfeiffer R., Beerman M., Struewing J., Chanock S. and Bergen A., (2003), BMC Biotech., 3, 110.

2. Zayed A., Shoeib T., Taylor S. E., Jones G. D. D., Thomas A. L., Wood J. P., Reid H. J. and Sharp B. L., (In Press, Corrected Proof) Int. J. Mass Spectrom., (DOI: 10.1016/j.ijms.2010.11.012).

3. English C. A., Merson S. and Keer J. T., (2006), Anal. Chem., 78, 4630-4633. 
4. $\quad$ Yang I., Han M. S., Yim Y. H., Hwang E. and Park S. R., (2004), Anal. Biochem., 335, 150-161.

5. Profrock D., Leonhard P. and Prange A., (2003), J. Anal. At. Spectrom., 18, 708-713.

6. Yeh C. and Jiang S., (2002), Anal., 127, 1324-1327.

7. Donald C. E., Stokes P., O’Connor G. and Woolford A. J., (2005), J. Chromatogr. B, 817, 173-182

8. Andrews C., Vouros P. andHarsch A., (1999), J. Chromatogr. A, 856, 515-26.

9. Brennan R. G., Rabb S. A., Holden M. J., Winchester M. R. and Turk G. C., (2009), Anal. Chem., 81, 3414-3420.

10. Bruchert W. and Bettmer J., (2006), J. Anal. At. Spectrom., 21, 1271-1276.

11. Siethoff C., Feldmann I., Jakubowski N. and Linscheid M., (1999), J. Mass Spectrom., , 34, 421-426.

12. Edler M., Jakubowski N. and Linscheid M., (2006), J. Mass Spectrom., 41, 507-516.

13. Edler M., Jakubowski N. and Linscheid M., (2005), Anal. Bioanal., 381, 205-211.

14. Garcia Sar D., Montes-Bayâon M., Aguado Ortiz L., Blanco-Gonzâalez E., Sierra L. and Sanz-Medel A., (2008), Anal. Bioanal., 390, 37-44.

15. Liang F., (2008), Chin. J. Anal.Chem., 36, 1097-1100.

16. Fujii S., Inagaki K., Takatsu A., Yarita T. and Chiba K., (In Press, Corrected Proof ), J. Chromatogr. A, 18

17. Fujii S., Inagaki K., Takatsu A., Yarita T. and Chiba K., (2009), J. Chromatogr. A, 1216, 7488-7492 